\title{
A Label-Free Fluorescent AND Logic Gate Aptasensor for Sensitive ATP Detection
}

\author{
Jingjing Zhang, Chunzheng Yang, Chaoqun Niu, Chen Liu, Xuepin Cai, Jie Du * and Yong Chen * \\ State Key Laboratory of Marine Resource Utilization in South China Sea, College of Information Science \& \\ Technology, College of Materials and Chemical Engineering, Institute of Tropical Agriculture and Forestry, \\ Hainan University, Haikou 570228, China; zhangjingjingaoxue@163.com (J.Z.); chunzhengyang@163.com (C.Y.); \\ chaoqunniu@163.com (C.N.); chen_liu@126.com (C.L.); 13698954926@163.com (X.C.) \\ * Correspondence: dujie@hainu.edu.cn (J.D.); ychen2002@hainu.edu.cn (Y.C.)
}

Received: 30 August 2018; Accepted: 25 September 2018; Published: 29 September 2018

check for updates

\begin{abstract}
In this study, a label-free fluorescent, enzyme-free, simple, highly sensitive AND logic gate aptasensor was developed for the detection of adenosine triphosphate (ATP). Double-stranded deoxyribonucleic acid (DNA) with cohesive ends was attached to graphene oxide (GO) to form an aptasensor probe. ATP and single-stranded DNA were used as input signals. Fluorescence intensity of PicoGreen dye was used as an output signal. The biosensor-related performances, including the logic gate construction, reaction time, linearity, sensitivity, and specificity, were investigated and the results showed that an AND logic gate was successfully constructed. The ATP detection range was found to be 20 to $400 \mathrm{nM}\left(\mathrm{R}^{2}=0.9943\right)$ with limit of detection (LOD) of $142.6 \mathrm{pM}$, and the sensitivity range was $1.846 \times 10^{6}$ to $2.988 \times 10^{6} \mathrm{M}^{-1}$. This method for the detection of ATP has the characteristics of being simple, low cost, and highly sensitive.
\end{abstract}

Keywords: ATP detection; label-free fluorescence; enzyme-free; graphene oxide; logic gate

\section{Introduction}

Adenosine triphosphate (ATP) is a direct source of energy in the body and has a great influence on biological processes [1,2]. Many scholars have shown that the concentration of ATP is closely related to the health of the human body. For example, low concentrations of ATP can affect the metabolic activity of organisms, resulting in biological cell damage and loss of vitality [3,4], and high concentrations of ATP may cause hypoxia, hypoglycemia, and Parkinson's disease [5]. Therefore, it is very necessary to develop a quantitative detection method for ATP.

Fluorescent biosensors have been widely used to detect substances such as ions, nucleic acids, organic molecules, and proteins [6-8]. There are two common methods for improving the sensitivity of deoxyribonucleic acid (DNA) fluorescence sensors, which are: increasing the output signal or suppressing the background signal. Common methods for signal amplification include strand displacement amplification [9-12], rolling circle replication [13], and the use of DNA enzymes [14-17], etc. However, although these methods can effectively increase the sensitivity of a sensor, they usually suffer from large background signal and require the use of biological enzymes. Enzymes are easily affected by reaction temperature and $\mathrm{pH}$ and are relatively expensive to use.

Compared with signal amplification, the background signal suppression method can lead to the design of a sensor with a simpler structure. The inhibition of the background signal can be achieved using graphene oxide (GO) [18-20], gold nanoparticles [21,22], magnetic nanoparticles [23], two-dimensional sheet metal-organic frameworks [24] as a quencher, which increases the sensitivity of the sensor. However, these materials usually involve the use of DNA with fluorescent labels, resulting in the detection method being relatively high cost. Therefore, label-free fluorescence methods are 
favored by researchers. Dyes, such as PicoGreen [25,26], thiazole orange (TO) [27], and SYBR Green I [28], intercalate in double-stranded DNA to produce fluorescence, but do not fluoresce in single strands of DNA. Thioflavin T dye forms an G-quadruplex complex with the G-rich aptamer and results in high fluorescence signal $[29,30]$. These dyes have the advantages of being simple, rapid to use, and low in cost. However, the disadvantage of the dyes is that they do not use signal amplification or suppression of the background signal to increase the sensitivity of the sensor. After a literature search, no reports were found on the detection of ATP using a simultaneous label-free, enzyme-free, and background signal inhibition method.

The application of molecular computers in medicine, nanotechnology, and biotechnology is very significant. Molecular logic gates form the hardware basis of molecular computers and can perform various molecular Boolean operations. Up to now, many logic gates have been constructed, such as AND, INH+NINH, and INHIBIT [19,31,32]. Although many molecular logic gates have been established, there is still a need to construct logic gates that are simpler, more sensitive, and are lower in cost. For these reasons, in this work, GO and PicoGreen dye were used to construct biosensors that have a simple structure for highly sensitive, label-free fluorescence, and enzyme-free ATP detection. It is hoped that the general method developed in this work can be adopted for the detection of various different proteins and ions.

\section{Materials and Methods}

\subsection{Reagents and Materials}

ATP, cytidine triphosphate (CTP), uridine triphosphate (UTP), guanosine triphosphate (GTP), and PicoGreen dye were purchased from Shanghai Yi Sheng Technology Co., Ltd. (Shanghai, China). All oligonucleotides were supplied by Beijing Genomics Institute (Beijing, China). The sequences of DNA-T, DNA-M, and DNA-M' are listed in detail in Table 1. PicoGreen dsDNA quantitation reagent was purchased from Shanghai Yi Sheng Biotechnology Co., Ltd. (Shanghai, China). Graphene oxide sol (graphene oxide content: $1 \mathrm{wt} \%$ ) was purchased from Shanghai Aladdin Biochemical Technology Co., Ltd. (Shanghai, China). Other reagents were purchased from Beijing Lian Shi Yun Shang Network Technology Co., Ltd. (Bejing, China).

Table 1. DNA sequences.

\begin{tabular}{cc}
\hline Oligonucleotide & Sequence \\
\hline DNA-T & $5^{\prime}$-CGC GCG ACC TGG GGG AGT ATT GCG GAG GAA GGT-3' \\
DNA-M & $5^{\prime}$-ACC TTC CTC CCC AGG T-3' \\
DNA-M & 5'-ACC TGG GGA GGA AGG T-3' \\
\hline
\end{tabular}

\subsection{The Process Used for Detection}

All reagent dilutions were performed using a buffer $(10 \mathrm{mmol} / \mathrm{L}$ Tris, $50 \mathrm{mmol} / \mathrm{L} \mathrm{NaCl}$, $10 \mathrm{mmol} / \mathrm{L} \mathrm{MgCl}_{2}, \mathrm{pH} 7.5$ and ultradeionization). $1 \mu \mathrm{M}$ DNA-T and $1 \mu \mathrm{M}$ DNA-M were mixed and the resulting mixture was then heated to $95{ }^{\circ} \mathrm{C}$ for $5 \mathrm{~min}$. Subsequently the mixture was cooled to room temperature in a furnace before finally being stored in a refrigerator at $4{ }^{\circ} \mathrm{C}$. DNA-M $\mathrm{M}^{\prime}$ was also heated to $95^{\circ} \mathrm{C}$ for $5 \mathrm{~min}$, and was then placed in a refrigerator at about $-20^{\circ} \mathrm{C}$ for $5 \mathrm{~min}$, and was then finally stored at $4{ }^{\circ} \mathrm{C}$ in the refrigerator. the PicoGreen dye was diluted to 200 -fold by buffer. The GO was diluted to 100 -fold by buffer. In all of the experiments, the total amount of buffer used was $1825 \mu \mathrm{L}$, the $1 \mu \mathrm{M}$ DNA-T and DNA-M mixture totaled $88 \mu \mathrm{L}$, the amount of $1 \mu \mathrm{M}$ DNA-M ${ }^{\prime}$ used was $90 \mu \mathrm{L}$, the spectral detection of PicoGreen dye was achieved using $40 \mu \mathrm{L}$ of dye, the reaction time of the detection of the PicoGreen dye was achieved using $30 \mu \mathrm{L}$ of dye, and a total of $10 \mu \mathrm{L}$ of GO was used. Before each experiment, the buffer and reagent were placed in a $2 \mathrm{~mL}$ sample tube, and the reaction mixture was kept for at least $3 \mathrm{~h}$ at room temperature. 


\subsection{The Selectivity Assays}

The blank sensing system was made up of $1825 \mu \mathrm{L}$ buffer, DNA-T + DNA-M mixture totaled $88 \mu \mathrm{L}, 90 \mu \mathrm{L}$ DNA-M', $10 \mu \mathrm{L}$ GO and $40 \mu \mathrm{L}$ PicoGreen dye. The ATP sensing system consisted of the blank sensing system and $200 \mu \mathrm{L}$ of $10 \mu \mathrm{M}$ ATP. The UTP sensing system consisted of the blank sensing system and $200 \mu \mathrm{L}$ of $10 \mu \mathrm{M}$ UTP. The CTP sensing system consisted of the blank sensing system and $200 \mu \mathrm{L}$ of $10 \mu \mathrm{M}$ CTP. The GTP sensing system consisted of the blank sensing system and $200 \mu \mathrm{L}$ of $10 \mu \mathrm{M}$ GTP. The mixture sensing system was made up of the blank sensing system, $200 \mu \mathrm{L}$ of $10 \mu \mathrm{M}$ ATP, $200 \mu \mathrm{L}$ of $10 \mu \mathrm{M}$ UTP, $200 \mu \mathrm{L}$ of $10 \mu \mathrm{M}$ CTP, and $200 \mu \mathrm{L}$ of $10 \mu \mathrm{M}$ GTP. After the sensing systems incubating for $3 \mathrm{~h}$, fluorescence intensity was tested by the proposed method.

\subsection{ATP Detection in Real Urine Samples}

A healthy adult urine was obtained from Hainan University hospital (Haikou, China). The urine samples were centrifuged at 13,000 r/min for $3 \mathrm{~min}$. The resulting supernatants were subsequently diluted to 10 -fold with buffer solution and the $\mathrm{pH}$ of the resulting solutions was 7.5. ATP was added in diluted urine at concentrations of 100, 300 and $500 \mathrm{nM}$, respectively, repeating the measurement three times. The recovery was then computed.

\subsection{Fluorescence Spectroscopy}

The change in the fluorescence intensity of the sensing liquid in a $10 \mathrm{~mm}$ square quartz cuvette was recorded using a fluorescence spectrometer (RF-6000, Shimadzu, Tokyo, Japan) with magnetic stirring. The spectral detection parameters used were an emission wavelength of $480 \mathrm{~nm}$ and a scanning range of $495 \mathrm{~nm}$ to $700 \mathrm{~nm}$. The reaction time program detection parameters used were an emission wavelength of $480 \mathrm{~nm}$ and an excitation wavelength of $520 \mathrm{~nm}$.

\section{Results and Discussion}

\subsection{Construction of an AND Logic Gate}

ATP and DNA-M $\mathrm{M}^{\prime}$ were used as input signals, and the fluorescence intensity change of PicoGreen was used as an output signal to construct an AND logic gate, a schematic overview of which is shown in Figure 1. The input signal was 1 if ATP or DNA-M ${ }^{\prime}$ were present, if not, it was 0. Meanwhile, at a wavelength of $527 \mathrm{~nm}$, if the PicoGreen fluorescence intensity increased, the output signal was 1, if not, the output signal was 0. As shown in Figure 1, DNA-T and DNA-M double strands were used as a sensor probe and GO was used to inhibit the background signal. If both ATP and DNA-M' were not present, the input signal was $(0,0)$. The DNA-T and DNA-M double strands adsorbed on the surface of GO through $\pi-\pi$ stacking leading to significant fluorescence quenching and an output signal of 0 . In the absence of ATP or DNA-M ${ }^{\prime}$, the input signal was $(0,1)$ or $(1,0)$. All of the DNA was found to adsorb on GO and the fluorescence of the probe was obviously quenched and the output signal was 0 . However, when ATP and DNA-M' $\mathrm{M}^{\prime}$ were introduced into the system, the input signal was $(1,1)$. The binding of ATP and a DNA-T chain led to the release of DNA-M. DNA-M and DNA-M' combined to form double-stranded DNA, which was released from the surface of GO due to the weaker affinity between the double strands and GO. PicoGreen dye was embedded in the double-stranded DNA and the fluorescence was significantly enhanced as a result, with an output signal of 1 . 


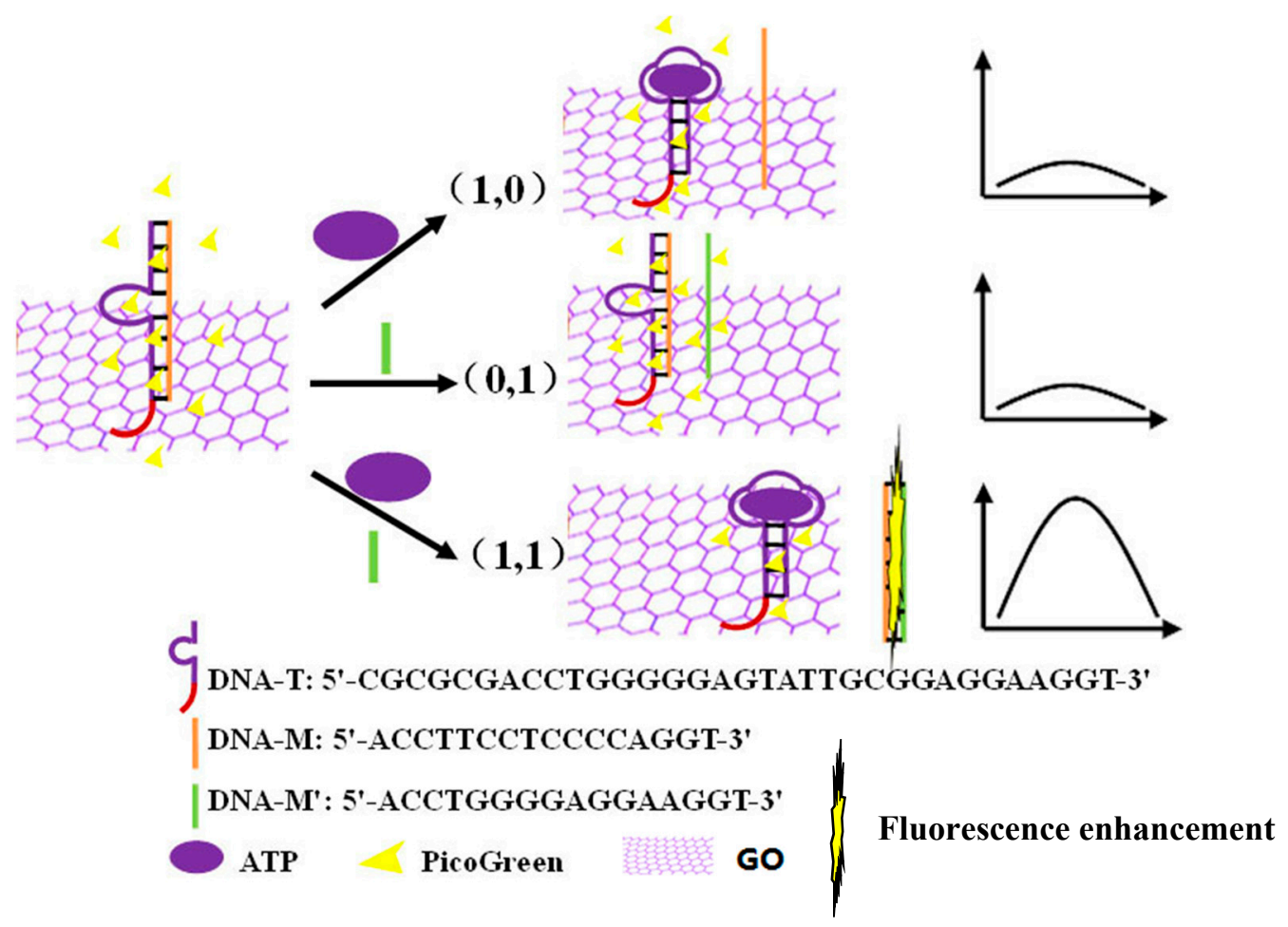

Figure 1. The principle of AND logic gate construction.

In order to verify the feasibility of the AND logic gate, spectral analysis was performed, as shown in Figure 2A. The a-curve in Figure 2A shows that in the absence of both ATP and DNA-M ${ }^{\prime}$, the fluorescence intensity at $527 \mathrm{~nm}$ (the following fluorescence values are all at $527 \mathrm{~nm}$ ) was 75.28 a.u. When double-stranded DNA with sticky ends adsorbed onto graphene oxide through $\pi-\pi$ stacking, a lower fluorescence value was observed due to fluorescence resonance energy transfer (FRET). The b-curve in Figure 2A shows the fluorescence intensity value of 92.82 a.u. in the presence of DNA-M $\mathrm{M}^{\prime}$ only. Since the DNA-M' base and the DNA-T base fragment are identical, DNA-M ${ }^{\prime}$ could not open the DNA duplex (DNA-T + DNA-M'). The sticky-ended DNA double-strands and DNA-M' single-strands all adsorbed onto the GO, resulting in the occurrence of FRET, which led to lower fluorescence values being observed. The c-curve in Figure 2A shows that the fluorescence intensity value was only 103.20 a.u. in the presence of ATP. ATP can open DNA double strands (DNA-T + DNA-M ${ }^{\prime}$ ), to form hairpins with sticky ends, resulting in the release of DNA-M. All of the DNA was adsorbed on GO, which led to the occurrence of FRET, resulting in poor fluorescence. However, in the presence of both ATP and DNA-M' ${ }^{\prime}$, the fluorescence intensity was 359.05 a.u., as shown by the d-curve, also in Figure 2A. Due to ATP being bound to DNA-T, DNA-M was released. DNA-M' formed a perfectly complementary double strand with DNA-M, which was then released from the surface of GO due to the weaker affinity between the double strand and GO. PicoGreen dye embedded in the double strand and produced relatively strong fluorescence [25]. A comparison of the d-curve with the other three curves (the a-, b-, and c-curves) showed that the fluorescence intensity was significantly increased in the presence of both ATP and DNA-M'.

To further construct the logic gate, ATP and DNA- $\mathrm{M}^{\prime}$ were used as input signals. When they were present, the input signal was 1 , otherwise it was 0 . The differences between the peaks of the four curves in Figure 2A and the peak of the a-curve were taken as the output signal, respectively. If the fluorescence intensity difference, $\Delta \mathrm{F}$, was greater than 30 a.u., the output signal was 1 , otherwise it was 0 . The results are shown in Figure $2 \mathrm{~B}$ and Table 2. Figure $2 \mathrm{~B}$ shows that the output was 0 when the inputs were $(0,0),(0,1)$, and $(1,0)$. However, when the input was $(1,1)$, the output was 1 , which matches Boolean AND logic. Therefore, using the above method, an AND logic gate was constructed and a schematic representation of the AND logic gate is shown in Figure 3. 

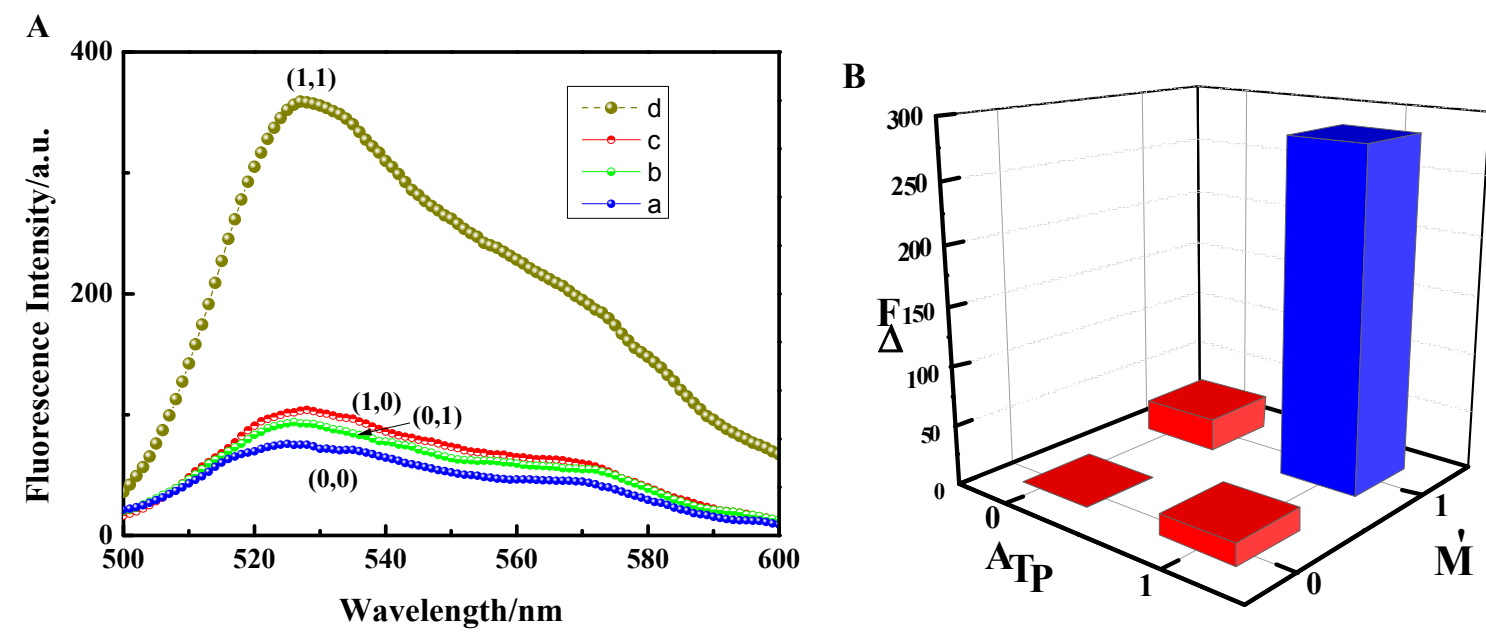

Figure 2. (A) Fluorescence emission spectra under different conditions: (a) DNA-T, DNA-M, and GO; (b) DNA-T, DNA-M, GO, and DNA-M'; (c) DNA-T, DNA-M, GO, and ATP; (d) DNA-T, DNA-M, GO, DNA-M', and ATP. (B) Logical histogram.

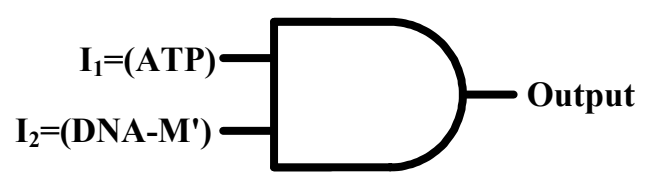

Figure 3. Schematic of an AND logic gate.

Table 2. A Boolean operation list.

\begin{tabular}{ccc}
\hline $\boldsymbol{I} \mathbf{1}=($ ATP $)$ & $\boldsymbol{I} \mathbf{2}=\left(\mathbf{D N A}-\boldsymbol{M}^{\prime}\right)$ & Output $=(\boldsymbol{\Delta} \boldsymbol{F})$ \\
\hline 0 & 0 & 0 \\
0 & 1 & 0 \\
1 & 0 & 0 \\
1 & 1 & 1 \\
\hline
\end{tabular}

\subsection{An Investigation into the Reaction Time}

To further verify the feasibility of the principle, timed detection was carried out, as shown in Figure 4. Figure 4A shows that the fluorescence intensity rapidly decreased when GO was added. It was demonstrated that the GO has the effect of suppressing the background signal, which is consistent with what has been described in the literature $[18,19]$ and the a-curve shown in Figure 2A. As shown in Figure 4B,C, the fluorescence intensity was found to slightly change after adding ATP or DNA-M'. Due to all of the DNA being adsorbed on the surface of GO through $\pi-\pi$ stacking, FRET occurred, resulting in a lower fluorescence value. This was illustrated by the fact that the fluorescence intensity was relatively weak when only ATP or DNA-M' $\mathrm{M}^{\prime}$ was present as an input, which further validated the b-curve and c-curve data shown in Figure 2A. Figure 4D shows that the fluorescence intensity rapidly increased when the DNA- $\mathrm{M}^{\prime}$ single strands were added. As DNA-M $\mathrm{M}^{\prime}$ rapidly formed a completely complementary DNA duplex with DNA-M, it detached from the surface of the GO. The PicoGreen dye intercalated into the double-stranded DNA, leading to the generation of strong fluorescence. This proved that the fluorescence intensity became stronger when ATP and DNA-M' were simultaneously used as inputs, which also verified the d-curve data shown in Figure 2A. Therefore, it can be concluded that Figure 4 is consistent with what has been described in Figure 2A and the principle is feasible. 

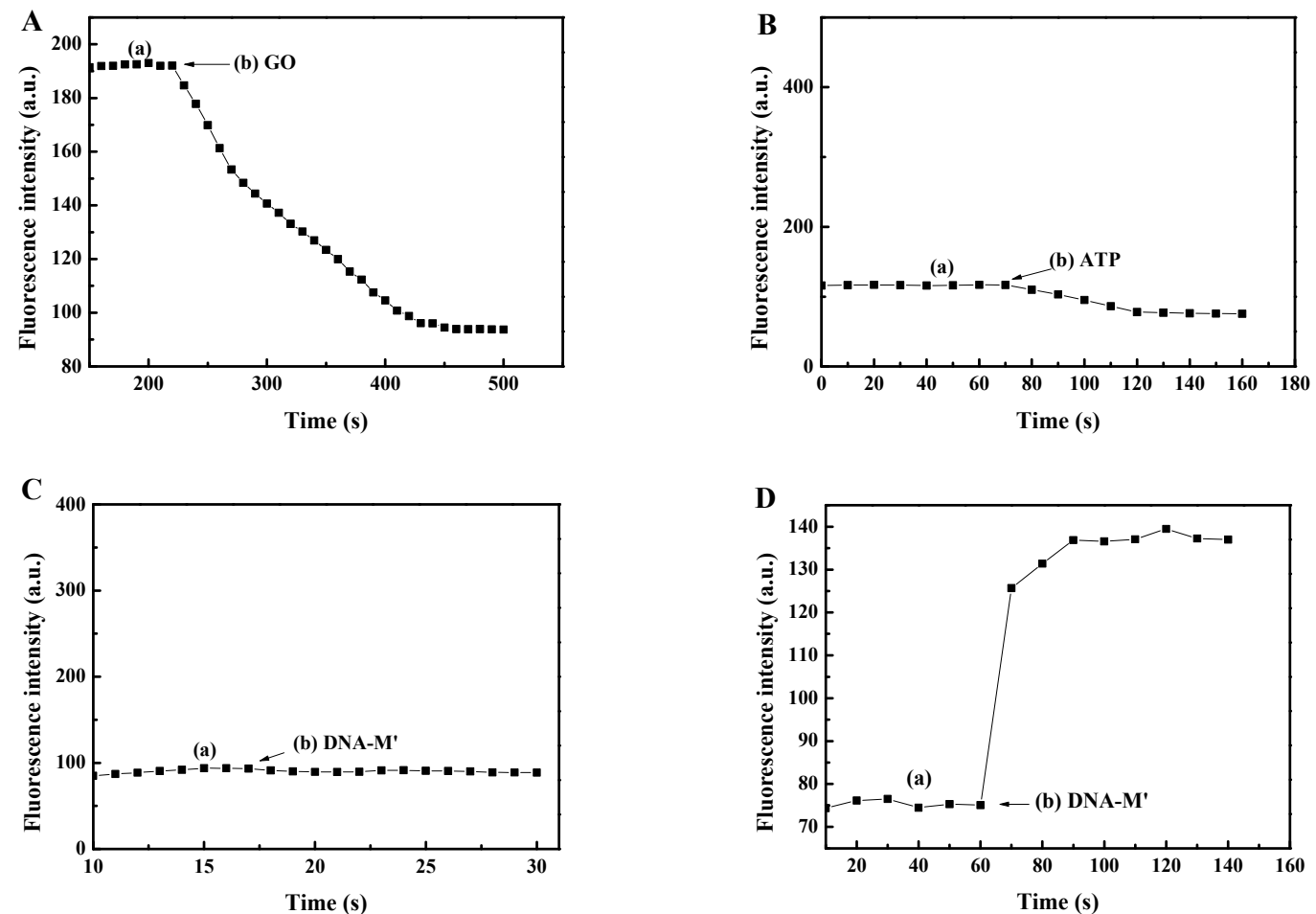

Figure 4. The investigation of the reaction time: (A) (a) DNA-T and DNA-M, (b) GO; (B) (a) DNA-T and DNA-M, (b) $200 \mu \mathrm{L}$ of $10 \mu \mathrm{M}$ ATP; (C) (a) DNA-T, DNA-M, and GO, (b) DNA-M'; (D) (a) DNA-T, DNA-M, $200 \mu \mathrm{L}$ of $10 \mu \mathrm{M}$ ATP and GO, (b) DNA-M'.

\subsection{Analysis of the Linearity and Sensitivity}

The $0 \mathrm{nM}$ ATP curve shown in Figure 5A was used as the initial value, $\mathrm{F}_{0}$, and the other curve peaks were used as the final $\mathrm{F}$ values. The linearity is shown in Figure 5B. The linear correlation coefficient $\mathrm{R}^{2}$ was found to be 0.9943 , which proves that the sensor has very high linearity. The linear equation was $Y=0.0278+0.00181 \mathrm{X}$ and the measurement range was found to be $20-400 \mathrm{nM}$. In this linear range, the concentration of target ATP can be estimated quantitatively using an equation.

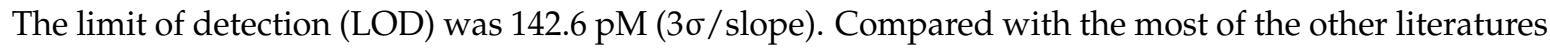
(Table 3), this sensor has higher linearity and smaller detection limit. Therefore, it can be concluded that this method is very suitable for the detection of ATP over this linear range.
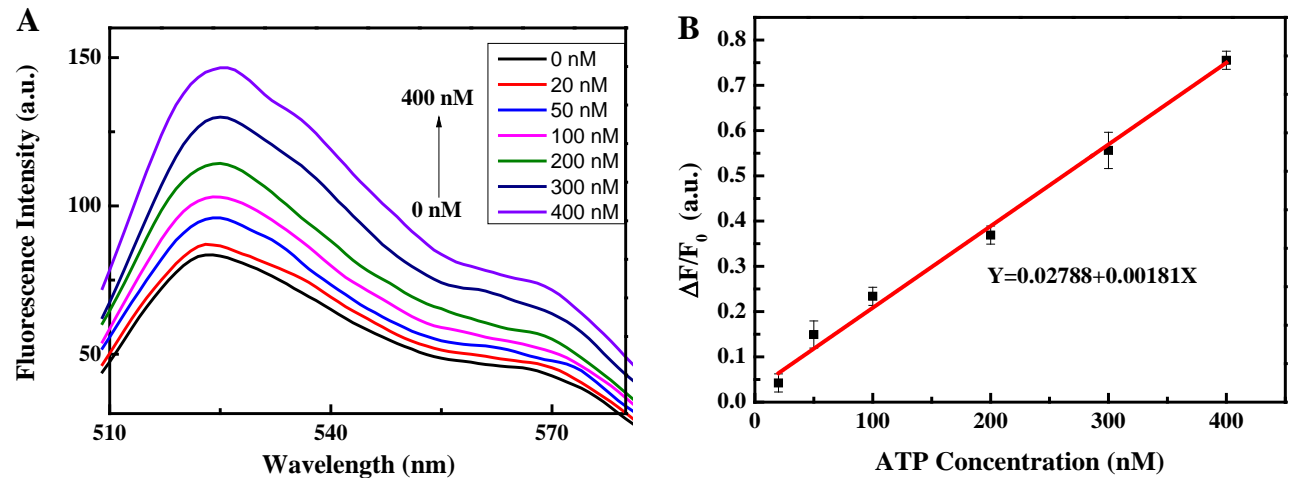

Figure 5. Cont. 


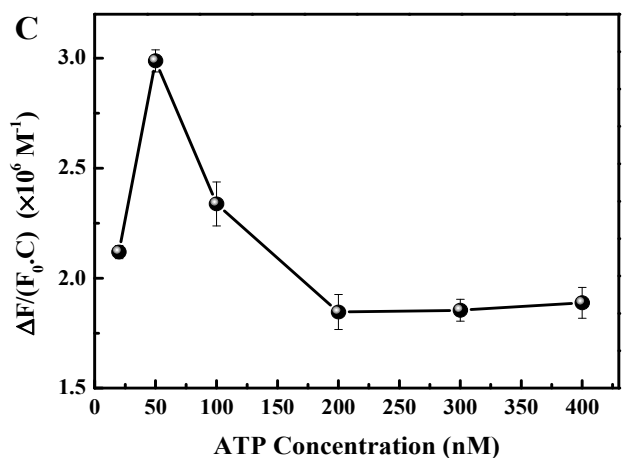

Figure 5. (A) Spectral detection at different ATP concentrations; (B) the linearity of the sensor; (C) the sensor sensitivity. DNA-T, DNA-M, DNA-M', GO, and ATP (0 nM, 20 nM, 50 nM, 100 nM, 200 nM, $300 \mathrm{nM}, 400 \mathrm{nM})$.

Table 3. Comparison of other methods for ATP detection.

\begin{tabular}{|c|c|c|c|c|}
\hline Methods & LOD & Linear Range & $\begin{array}{c}\text { Correlation } \\
\text { Coefficient }\left(\mathbf{R}^{2}\right)\end{array}$ & Reference \\
\hline $\begin{array}{l}\text { A Universal and Label-free } \\
\text { Aptasensor }\end{array}$ & $23.4 \mathrm{nM}$ & 0-10 mM & $\mathrm{N} / \mathrm{A}$ & [33] \\
\hline $\begin{array}{l}\text { An "off-on" Phosphorescent } \\
\text { Aptasensor Switch }\end{array}$ & $0.9 \mathrm{nM}$ & $2 \mathrm{nM}-9 \mu \mathrm{M}$ & 0.995 & {$[34]$} \\
\hline $\begin{array}{c}\text { Hollow NiFe PBA Derived } \\
\text { NiOxFeOy@mC }\end{array}$ & $1.62 \mathrm{fM}$ & $8.26 \mathrm{fM}-8.26 \mathrm{nM}$ & 0.996 & [35] \\
\hline Photoinduced Regeneration & $0.5 \mathrm{nM}$ & $1 \mathrm{nM}-100 \mu \mathrm{M}$ & 0.996 & [36] \\
\hline $\begin{array}{l}\text { Mixed Self-assembled Aptamer and } \\
\text { Zwitterionic Peptide }\end{array}$ & $0.1 \mathrm{pM}$ & $0.1 \mathrm{pM}-5 \mathrm{nM}$ & 0.9984 & {$[37]$} \\
\hline $\begin{array}{l}\text { Silver Nanoparticle-decorated } \\
\text { Graphene Oxide }\end{array}$ & $5.0 \mathrm{nM}$ & $10-850 \mathrm{nM}$ & 0.9901 & [38] \\
\hline $\begin{array}{l}\text { Peroxidase-like Activity of } \\
\text { DNAzyme }\end{array}$ & $2.4 \mathrm{nM}$ & $5-230 \mathrm{nM}$ & 0.9854 & [39] \\
\hline Unmodified Gold Nanoparticles & $0.1 \mu \mathrm{M}$ & $0-5 \mu \mathrm{M}$ & 0.9989 & [40] \\
\hline $\begin{array}{l}\text { Oligonucleotide-templated } \\
\text { Fluorescent Copper Nanoparticles }\end{array}$ & $500 \mathrm{nM}$ & $1-80 \mathrm{mM}$ & 0.9901 & [41] \\
\hline $\begin{array}{l}\text { Target-induced Conformational } \\
\text { Change of Dual-hairpin DNA }\end{array}$ & $1.4 \mathrm{nM}$ & $5 \mathrm{nM}-1 \mu \mathrm{M}$ & 0.9976 & {$[42]$} \\
\hline GO-Based Aptamer Logic Gates & $142.6 \mathrm{pM}$ & $20-400 \mathrm{nM}$ & 0.9943 & This work \\
\hline
\end{tabular}

Figure $5 \mathrm{C}$ shows that the sensitivity first increased and then decreased. The sensitivity when $50 \mathrm{nM}$ of ATP was used was found to be higher than that using $20 \mathrm{nM}$ of ATP. One possible reason for this was that $50 \mathrm{nM}$ of ATP opened up more double strands (DNA-T + DNA-M) of DNA and released more DNA-M. DNA-M ${ }^{\prime}$ and DNA-M were then able to form completely complementary double strands and detach from the GO surface. PicoGreen dye embedded in the double-stranded $\mathrm{DNA}$, resulting in strong fluorescence. Thus, the relative change rate of the fluorescence, $\Delta \mathrm{F} / \mathrm{F}_{0}$, of $50 \mathrm{nM}$ of ATP was greater than that of $20 \mathrm{nM}$ of ATP, as shown in Figure 5B. In addition, the difference between the $50 \mathrm{nM}$ ATP and $20 \mathrm{nM}$ ATP concentration was small. From the sensitivity formula $\Delta \mathrm{F} /\left(\mathrm{F}_{0} \cdot \mathrm{C}\right)$, it can be seen that the $20 \mathrm{nM}$ ATP sensitivity was lower than that of the $50 \mathrm{nM}$ ATP sensitivity. From Figure 5B, it can also be seen that the relative change rates of ATP for 100, 200, 300 and $400 \mathrm{nM}$ were higher than that of $50 \mathrm{nM}$ of ATP, but their concentrations were much greater than $50 \mathrm{nM}$. Therefore, from the sensitivity formula $\Delta \mathrm{F} /\left(\mathrm{F}_{0} \cdot \mathrm{C}\right)$, it can be deduced that their sensitivity is less than that of the $50 \mathrm{nM}$ of ATP. The sensitivity range of the sensor was found to be $1.846 \times 10^{6}$ to $2.988 \times 10^{6} \mathrm{M}^{-1}$, as shown in Figure 5C. It can therefore be concluded that this method is very sensitive for detecting ATP. 


\subsection{Analysis of the Selectivity}

Figure 6 shows that the fluorescence intensity of the blank sensing system was relatively weak because the blank sensing system didn't involve ATP. The fluorescence intensities of UTP, CTP, and GTP sensing system were found to be similar to the background fluorescence due to UTP, CTP, and GTP not being able to open up double-stranded DNA (DNA-T + DNA-M). The fluorescence intensity of the mixture sensing system was found to be lower than that of the ATP sensing system. Because in the mixture sensing system and the ATP sensing system, the ATP concentration was $753.8 \mathrm{nM}$ and $887.7 \mathrm{nM}$, respectively. The ATP concentration of the mixture sensing system was $133.9 \mathrm{nM}$ lower than that of the ATP sensing system, which resulted in the mixture sensing system decreased in fluorescence intensity. Therefore, it can be concluded that this sensor has strong specificity and is therefore very suitable for the detection of ATP.

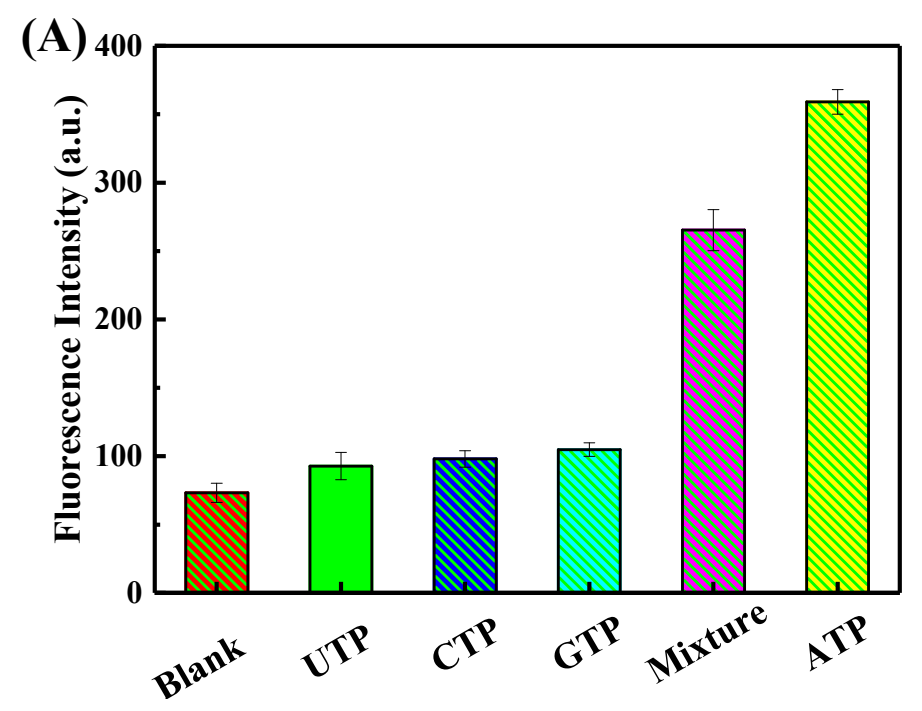

(B)

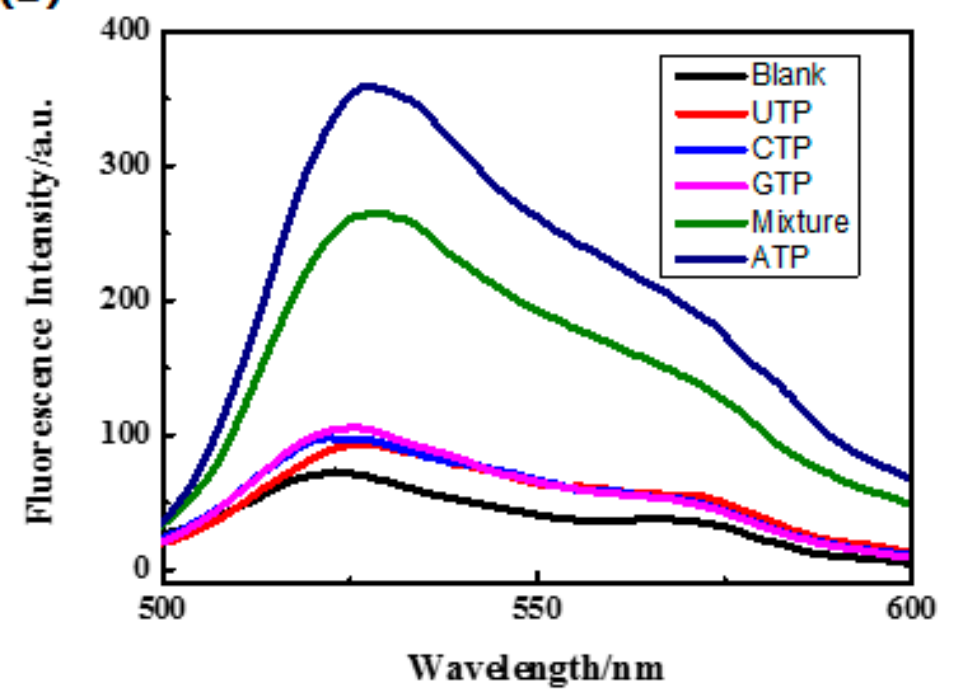

Figure 6. (A) The selectivity assays. Blank sensing system consisted of DNA-T, DNA-M, DNA-M', GO and PicoGreen dye; (B) ATP sensing system consisted of the blank sensing system and $200 \mu \mathrm{L}$ of $10 \mu \mathrm{M}$ ATP; UTP sensing system consisted of the blank sensing system and $200 \mu \mathrm{L}$ of $10 \mu \mathrm{M}$ UTP; CTP sensing system consisted of the blank sensing system and $200 \mu \mathrm{L}$ of $10 \mu \mathrm{M}$ CTP; GTP sensing system consisted of the blank sensing system and $200 \mu \mathrm{L}$ of $10 \mu \mathrm{M}$ GTP; Mixture sensing system consisted of the blank sensing system, $200 \mu \mathrm{L}$ of $10 \mu \mathrm{M}$ ATP, $200 \mu \mathrm{L}$ of $10 \mu \mathrm{M}$ UTP, $200 \mu \mathrm{L}$ of $10 \mu \mathrm{M} \mathrm{CTP}$, and $200 \mu \mathrm{L}$ of $10 \mu \mathrm{M}$ GTP. 


\subsection{Detection of ATP Concentration in Real Urine Samples}

In order to verify the practicability of the method, ATP was added into human urine in order to carry out standard recovery tests. As shown in Table 4, the recovery rate was found to be between 102 and 104.2, and the results indicate that the method is reliable and has great potential for ATP detection in actual urine samples.

Table 4. Detection of ATP concentration in real urine samples.

\begin{tabular}{|c|c|c|c|c|c|}
\hline & ATP & & Proposed & Method & \\
\hline \multirow[t]{2}{*}{ Samples } & Added & Found & Recovery & Standard Deviation $(n=3)$ & Relative Standard Deviation $(n=3)$ \\
\hline & $(\mathrm{nM})$ & (nM) & $(\%)$ & $(\mathrm{nM})$ & $(\%)$ \\
\hline 1 & 100.00 & $\begin{array}{c}114.368 \\
102.745 \\
95.551\end{array}$ & 104.2 & 7.75 & 7.4 \\
\hline 2 & 200.00 & $\begin{array}{l}211.597 \\
203.427 \\
199.758\end{array}$ & 102.5 & 4.95 & 2.4 \\
\hline 3 & 300.00 & $\begin{array}{l}308.788 \\
305.366 \\
304.202\end{array}$ & 102.0 & 1.95 & 0.6 \\
\hline
\end{tabular}

\section{Conclusions}

In summary, a label-free, fluorescent, enzyme-free, highly sensitive AND logic gate biosensor was developed for ATP detection. By suppressing the background signal with GO, the sensitivity of the sensor was improved. The sensor was found to have high sensitivity and linearity and was able to detect lower concentrations of ATP with strong selectivity. Therefore, a simple, low-cost, highly sensitive method for the detection of ATP was developed that can be used as a universal detection method for the detection of ions, proteins, and other substances.

Author Contributions: J.Z. and C.Y. performed the experiments and wrote the paper; C.N., C.L. and X.C. analyzed the data, and J.D. and Y.C. conceived and designed the experiments.

Funding: This research was funded by the Natural Science Foundation of Hainan Province (Grant Nos. 518QN215, 2018CXTD332), the National Nature Science Foundation of China (Grant No. 21763009), Hainan Province graduate student innovative research projects (Grant Nos. Hys2018-59, Hys2018-60).

Conflicts of Interest: The authors declare no conflicts of interest.

\section{References}

1. Imamura, H.; Nhat, K.P.; Togawa, H.; Saito, K.; Iino, R.; Kato-Yamada, Y.; Nagai, T.; Noji, H. Visualization of ATP levels inside single living cells with fluorescence resonance energy transfer-based genetically encoded indicators. Proc. Natl. Acad. Sci. USA 2009, 106, 15651-15656. [CrossRef] [PubMed]

2. Yi, M.; Yang, S.; Peng, Z.; Liu, C.; Li, J.; Zhong, W.; Yang, R.; Tan, W. Two-photon graphene oxide/aptamer nanosensing conjugate for in vitro or in vivo molecular probing. Anal. Chem. 2014, 86, 3548-3554. [CrossRef] [PubMed]

3. Mo, R.; Jiang, T.; Gu, Z. Enhanced anticancer efficacy by ATP-mediated liposomal drug delivery. Angew. Chem. Int. Ed. Engl. 2014, 53, 5815-5820. [CrossRef] [PubMed]

4. Naito, M.; Ishii, T.; Matsumoto, A.; Miyata, K.; Miyahara, Y.; Kataoka, K. A phenylboronate-functionalized polyion complex micelle for ATP-triggered release of siRNA. Angew. Chem. Int. Ed. Engl. 2012, 51, 10751-10755. [CrossRef] [PubMed]

5. Gourine, A.V.; Llaudet, E.; Dale, N.; Spyer, K.M. Atp is a mediator of chemosensory transduction in the central nervous system. Nature 2005, 436, 108-111. [CrossRef] [PubMed]

6. Li, Q.; Li, S.; Chen, X.; Bian, L. A g-quadruplex based fluorescent oligonucleotide turn-on probe towards iodides detection in real samples. Food Chem. 2017, 230, 432-440. [CrossRef] [PubMed] 
7. Qiu, B.; Zhang, Y.S.; Lin, Y.B.; Lu, Y.J.; Lin, Z.Y.; Wong, K.Y.; Chen, G.N. A novel fluorescent biosensor for detection of target DNA fragment from the transgene cauliflower mosaic virus 35s promoter. Biosens. Bioelectron. 2013, 41, 168-171. [CrossRef] [PubMed]

8. Wang, K.; Liao, J.; Yang, X.; Zhao, M.; Chen, M.; Yao, W.; Tan, W.; Lan, X. A label-free aptasensor for highly sensitive detection of ATP and thrombin based on metal-enhanced picogreen fluorescence. Biosens. Bioelectron. 2015, 63, 172-177. [CrossRef] [PubMed]

9. Chen, H.G.; Ren, W.; Jia, J.; Feng, J.; Gao, Z.F.; Li, N.B.; Luo, H.Q. Fluorometric detection of mutant DNA oligonucleotide based on toehold strand displacement-driving target recycling strategy and exonuclease iii-assisted suppression. Biosens. Bioelectron. 2016, 77, 40-45. [CrossRef] [PubMed]

10. Wang, X.P.; Yin, B.C.; Wang, P.; Ye, B.C. Highly sensitive detection of micrornas based on isothermal exponential amplification-assisted generation of catalytic g-quadruplex dnazyme. Biosens. Bioelectron. 2013, 42, 131-135. [CrossRef] [PubMed]

11. Wei, Y.; Zhou, W.; Li, X.; Chai, Y.; Yuan, R.; Xiang, Y. Coupling hybridization chain reaction with catalytic hairpin assembly enables non-enzymatic and sensitive fluorescent detection of microRNA cancer biomarkers. Biosens. Bioelectron. 2016, 77, 416-420. [CrossRef] [PubMed]

12. Wang, Y.-M.; Liu, J.-W.; Duan, L.-Y.; Liu, S.-J.; Jiang, J.-H. Aptamer-based fluorometric determination of ATP by using target-cycling strand displacement amplification and copper nanoclusters. Microchim. Acta 2017, 184, 4183-4188. [CrossRef]

13. Zhou, F.; Li, B.; Ma, J. A linear DNA probe as an alternative to a molecular beacon for improving the sensitivity of a homogenous fluorescence biosensing platform for DNA detection using target-primed rolling circle amplification. RSC Adv. 2015, 5, 4019-4025. [CrossRef]

14. Zeng, S.; Huang, H.; Huang, Y.; Liu, X.; Qin, J.; Zhao, S.; Chen, Z.-F.; Liang, H. Label-free and amplified colorimetric assay of ribonuclease $\mathrm{h}$ activity and inhibition based on a novel enzyme-responsive dnazyme cascade. RSC Adv. 2015, 5, 43105-43109. [CrossRef]

15. Lu, C.H.; Li, J.; Lin, M.H.; Wang, Y.W.; Yang, H.H.; Chen, X.; Chen, G.N. Amplified aptamer-based assay through catalytic recycling of the analyte. Angew. Chem. Int. Ed. Engl. 2010, 49, 8454-8457. [CrossRef] [PubMed]

16. He, S.N.; Qu, L.; Tan, Y.; Liu, F.; Wang, Y.; Zhang, W.; Cai, Z.M.; Mou, L.S.; Jiang, Y.Y. A fluorescent aptasensor with product-triggered amplification by exonuclease iii digestion for highly sensitive ATP detection. Anal. Methods 2017, 9, 4837-4842. [CrossRef]

17. Ning, Y.; Wei, K.; Cheng, L.; Hu, J.; Xiang, Q. Fluorometric aptamer based determination of adenosine triphosphate based on deoxyribonuclease i-aided target recycling and signal amplification using graphene oxide as a quencher. Microchim. Acta 2017, 184, 1847-1854. [CrossRef]

18. Liu, X.; Yang, Y.; Hua, X.; Feng, X.; Su, S.; Huang, Y.; Fan, Q.; Wang, L.; Huang, W. An improved turn-on aptasensor for thrombin detection using split aptamer fragments and graphene oxide. Chin. J. Chem. 2015, 33, 981-986. [CrossRef]

19. Lv, H.; Li, S.; Liu, Y.; Wang, G.; Li, X.; Lu, Y.; Wang, J. A reversible fluorescent inhibit logic gate for determination of silver and iodide based on the use of graphene oxide and a silver-selective probe DNA. Microchim. Acta 2015, 182, 2513-2520. [CrossRef]

20. Luo, J.; Shen, X.; Li, B.; Li, X.; Zhou, X. Signal amplification by strand displacement in a carbon dot based fluorometric assay for ATP. Mikrochim. Acta 2018, 185, 392. [CrossRef] [PubMed]

21. Jin, Y.; Li, H.; Bai, J. Homogeneous selecting of a quadruplex-binding ligand-based gold nanoparticle fluorescence resonance energy transfer assay. Anal. Chem. 2009, 81, 5709-5715. [CrossRef] [PubMed]

22. Yin, B.C.; Zuo, P.; Huo, H.; Zhong, X.; Ye, B.C. Dnazyme self-assembled gold nanoparticles for determination of metal ions using fluorescence anisotropy assay. Anal. Biochem 2010, 401, 47-52. [CrossRef] [PubMed]

23. Saberi, Z.; Rezaei, B.; Khayamian, T. A fluorescent aptasensor for analysis of adenosine triphosphate based on aptamer-magnetic nanoparticles and its single-stranded complementary DNA labeled carbon dots. Luminescence 2018, 33, 640-646. [CrossRef] [PubMed]

24. Hai, X.M.; Li, N.; Wang, K.; Zhang, Z.Q.; Zhang, J.; Dang, F.Q. A fluorescence aptasensor based on two-dimensional sheet metal-organic frameworks for monitoring adenosine triphosphate. Anal. Chim. Acta 2018, 998, 60-66. [CrossRef] [PubMed] 
25. Dragan, A.I.; Casas-Finet, J.R.; Bishop, E.S.; Strouse, R.J.; Schenerman, M.A.; Geddes, C.D. Characterization of picogreen interaction with dsdna and the origin of its fluorescence enhancement upon binding. Biophys. J. 2010, 99, 3010-3019. [CrossRef] [PubMed]

26. Lv, Z.; Liu, J.; Zhou, Y.; Guan, Z.; Yang, S.; Li, C.; Chen, A. Highly sensitive fluorescent detection of small molecules, ions, and proteins using a universal label-free aptasensor. Chem. Commun. 2013, 49, 5465-5467. [CrossRef] [PubMed]

27. Kang, B.H.; Gao, Z.F.; Li, N.; Shi, Y.; Li, N.B.; Luo, H.Q. Thiazole orange as a fluorescent probe: Label-free and selective detection of silver ions based on the structural change of i-motif DNA at neutral ph. Talanta 2016, 156-157, 141-146. [CrossRef] [PubMed]

28. Pu, W.; Zhao, H.; Huang, C.; Wu, L.; Xua, D. Fluorescent detection of silver(i) and cysteine using sybr green $\mathrm{i}$ and a silver(i)-specific oligonucleotide. Microchim. Acta 2012, 177, 137-144. [CrossRef]

29. Liu, H.; Ma, C.; Ning, F.; Chen, H.; He, H.; Wang, K.; Wang, J. A facile label-free g-quadruplex based fluorescent aptasensor method for rapid detection of ATP. Spectrochim. Acta A Mol. Biomol. Spectrosc. 2017, 175, 164-167. [CrossRef] [PubMed]

30. Song, Q.; Wang, R.; Sun, F.; Chen, H.; Wang, Z.; Na, N.; Ouyang, J. A nuclease-assisted label-free aptasensor for fluorescence turn-on detection of ATP based on the in situ formation of copper nanoparticles. Biosens. Bioelectron. 2017, 87, 760-763. [CrossRef] [PubMed]

31. Voelcker, N.H.; Guckian, K.M.; Saghatelian, A.; Ghadiri, M.R. Sequence-addressable DNA logic. Small 2008, 4, 427-431. [CrossRef] [PubMed]

32. Li, J.; Huang, Y.-Q.; Qin, W.-S.; Liu, X.-F.; Huang, W. An optical-logic system based on cationic conjugated polymer/DNA/intercalating dyes assembly for label-free detection of conformational conversion of DNA i-motif structure. Polym. Chem. 2011, 2, 1341. [CrossRef]

33. Kong, L.; Xu, J.; Xu, Y.; Xiang, Y.; Yuan, R.; Chai, Y. A universal and label-free aptasensor for fluorescent detection of ATP and thrombin based on sybr green i dye. Biosens. Bioelectron. 2013, 42, 193-197. [CrossRef] [PubMed]

34. Xiong, Y.; Cheng, Y.; Wang, L.; Li, Y. An "off-on" phosphorescent aptasensor switch for the detection of ATP. Talanta 2018, 190, 226-234. [CrossRef] [PubMed]

35. Tang, X.; Li, X.; Ma, D.-L.; Lu, L.; Qu, B. A label-free triplex-to-G-qadruplex molecular switch for sensitive fluorescent detection of acetamiprid. Talanta 2018, 189, 599-605. [CrossRef] [PubMed]

36. Zhang, X.; Song, C.; Yang, K.; Hong, W.; Lu, Y.; Yu, P.; Mao, L. Photoinduced regeneration of an aptamer-based electrochemical sensor for sensitively detecting adenosine triphosphate. Anal. Chem. 2018, 90, 4968-4971. [CrossRef] [PubMed]

37. Wang, G.; Su, X.; Xu, Q.; Xu, G.; Lin, J.; Luo, X. Antifouling aptasensor for the detection of adenosine triphosphate in biological media based on mixed self-assembled aptamer and zwitterionic peptide. Biosens. Bioelectron. 2018, 101, 129-134. [CrossRef] [PubMed]

38. Mashhadizadeh, M.H.; Naseri, N.; Mehrgardi, M.A. A simple non-enzymatic strategy for adenosine triphosphate electrochemical aptasensor using silver nanoparticle-decorated graphene oxide. J. Iran. Chem. Soc. 2017, 14, 2007-2016. [CrossRef]

39. Shahsavar, K.; Hosseini, M.; Shokri, E.; Ganjali, M.R.; Ju, H. A sensitive colorimetric aptasensor with a triplehelix molecular switch based on peroxidase-like activity of a dnazyme for ATP detection. Anal. Methods 2017, 9, 4726-4731. [CrossRef]

40. Mao, Y.; Fan, T.; Gysbers, R.; Tan, Y.; Liu, F.; Lin, S.; Jiang, Y. A simple and sensitive aptasensor for colorimetric detection of adenosine triphosphate based on unmodified gold nanoparticles. Talanta 2017, 168, $279-285$. [CrossRef] [PubMed]

41. Cai, Q.; Ge, J.; Xu, H.; Zhang, L.; Hu, Y.; Huang, Z.; Li, Z. A label-free aptasensor for highly sensitive ATP detection by using exonuclease i and oligonucleotide-templated fluorescent copper nanoparticles. Anal. Methods 2017, 9, 2710-2714. [CrossRef]

42. Jia, J.; Feng, J.; Chen, H.G.; Luo, H.Q.; Li, N.B. A simple electrochemical method for the detection of ATP using target-induced conformational change of dual-hairpin DNA structure. Sens. Actuators B Chem. 2016, 222, 1090-1095. [CrossRef]

(C) 2018 by the authors. Licensee MDPI, Basel, Switzerland. This article is an open access article distributed under the terms and conditions of the Creative Commons Attribution (CC BY) license (http://creativecommons.org/licenses/by/4.0/). 